Callomon, J. H. 1970: Geological map of Carlsberg Fjord - Fossilbjerget area. Meddr Grønland 168, $4,10 \mathrm{pp}$.

Donovan, D. T. 1957: The Jurassic and Cretaceous Systems in East Greenland. Meddr Grønland 155, $4,225 \mathrm{pp}$.

Grasmück, K. \& Trümpy, R. 1969: Triassic stratigraphy and general geology of the country around Fleming Fjord. Meddr Gronland 168, 2, I, 5-76.

Harris, T. M. 1926: The Rhaetic flora of Scoresby Sound, East Greenland. Meddr Grønland 68, 43-147. Harris, T. M. 1937: The fossil flora of Scoresby Sound, East Greenland. 5: Stratigraphic relations of the plant beds. Meddr Grenland 112, 2, $114 \mathrm{pp}$.

Hartz, N. 1896: Planteforsteninger fra Cap Stewart i Østgrønland, med en historisk oversigt. Meddr Gronland 19, 217-247.

Rosenkrantz, A. 1929: Preliminary account of the geology of the Scoresby Sound district. In Koch, L., The geology of East Greenland. Meddr Grenland 73, 2, 135-154.

Rosenkrantz, A. 1934: The Lower Jurassic rocks of East Greenland, I. Meddr Grønland 110, 1, 122 pp.

Surlyk, F. (in press): Upper Jurassic and Lower Cretaceous stratigraphy in southern Jameson Land, East Greenland. Bull. geol. Soc. Denmark 21.

\title{
PRELIMINARY RESULTS OF MAPPING THE UPPER JURASSIC AND LOWER CRETACEOUS SEDIMENTS OF MILNE LAND
}

\author{
E. Håkansson, T. Birkelund, C. Heinberg and P. Willumsen
}

\section{Introduction}

The Mesozoic sediments of eastern Milne Land were mapped during the 1970 field season (map 2).

The Upper Jurassic - Lower Cretaceous sequence of this area has been studied previously mainly by Rosenkrantz (1929), Aldinger (1935) and Callomon (1961). The rich faunas from the area have been described by Spath $(1935,1936)$ and Donovan (1964).

Rosenkrantz (1929) established two lithological divisions for the upper part of the sequence (Cape Leslie Formation and Hartz Fjeld Formation), while Aldinger (1935) investigated the whole sequence from the Caledonian crystalline basement at Charcot Bugt to the top of Hartz Fjeld. He divided the sequence into (a) Charcot Bugt Sandstone, (b) shale and marl from the Upper Oxfordian, (c) Pecten Sandstone from the Upper Oxfordian, (d) shale and marl from the Lower and Upper Kimmeridgian, (e) Glauconite Series from the Upper Kimmeridgian - Portlandian and (f) Hartz Fjeld Sandstone, the last of which includes parts of Rosenkrantz's Cape Leslie Formation. Aldinger's publication (1935) also included a geological map of the eastern part of the Mesozoic area. 
The biostratigraphical zonation was mainly worked out by Spath $(1935,1936)$ and later considerably refined by Callomon (1961).

Among the established lithological divisions only Charcot Bugt Sandstone and Hartz Fjeld Sandstone (as redefined by Aldinger, 1935) are satisfactory formational names, comprising well defined lithological units. For the sequence between these two units the provisional name the "shale and glauconite series" is used in this report. A new formation containing several members will be established elsewhere for this part of the sequence.

One of the authors (C.H.) payed special attention to the trace fossil assemblages, which have not previously been described from this region.

\section{Caledonian crystalline basement}

The Jurassic sequence overlies a basement of gneisses, migmatites and granites belonging to the East Greenland Caledonian fold-belt. The crystalline basement forms a very irregular erosional surface with a pronounced relief and is more or less kaolinised. The kaolinisation pre-dates the Jurassic transgression. The weathered crust now varies in thickness from 1 to less than $5 \mathrm{~m}$.

\section{Charcot Bugt Sandstone}

This is the most widespread formation in eastern Milne Land and the only one traceable outside Milne Land in the surrounding areas. Visits were made to several small outcrops beyond the main area shown on the map. These were situated up to 18 $\mathrm{km}$ to the north and up to $40 \mathrm{~km}$ to the south of the main area (on the eastern tip of Gåseland). The area originally covered by these sandstones was presumably considerably larger as the thickness of the formation preserved in most of these outliers is considerable, e.g. $15 \mathrm{~km}$ north of the main area it exceeds $150 \mathrm{~m}$.

Within the main sedimentary area the Charcot Bugt Sandstone crops out along the northern and western margins, while it is covered by younger sediments in most of the central area.

The irregular relief of the underlying surface is strongly reflected in the rapidly changing thickness of this formation, which varies from about $100 \mathrm{~m}$ to about $200 \mathrm{~m}$. This bottom relief is probably also responsible for the lithological variation in the basal sediments of the formation.

The bottom layers are in most places developed as a rather loose, unfossiliferous conglomerate up to $25 \mathrm{~m}$ thick, containing boulders up to $60 \mathrm{~cm}$ in size, but usually less than $20 \mathrm{~cm}$. The boulders and pebbles consist of poorly rounded basement rocks, quartz and (rarer) feldspar and rather well rounded quartzite.

On the other hand, in the north-western corner of the main sedimentary area the basal layers have a different character, probably caused by sedimentation near hill- 
tops of the underlying basement. The conglomerates in this area are very variable. At certain localities they are completely lacking. At one place the basal sandstone contains enormous boulders of basement rocks less kaolinised than the underlying basement itself. Elsewhere conglomerates are developed, strongly cemented with calcite, and most commonly alternating with beds of shaly siltstone or fine sandstone. These beds are highly fossiliferous. Many of the pebbles are fossils, especially corals, and autochthonous fossils also occur. In the fine-grained shales well-preserved trace fossils dominate. In still other north-western localities the basal layers are fine-grained conglomerates packed with fragmented ostreids. This type may locally have the characteristics of a shell gravel.

The occurrence in this area of abundant, colonial, hermatypic corals at this high latitude is most remarkable. All the fragments found, up to $20 \mathrm{~cm}$ in size, are conspecific and belong to Actinastrea? (S. Floris, pers. comm. 1971).

The fauna from these beds also includes abundant lamellibranchs, mostly ostreids but also pectinids, trigonids and others, belemnites, a few gastropods and a perisphinctid ammonite (one fragment). The trace fossils Curvolithus, Planolites and small, irregular endichnia occur in the fine-grained horizons. The corals in the conglomerates have been bored by lamellibranchs.

The basal layers of the Charcot Bugt Sandstone pass gradually up into the main part of the formation, becoming a rather monotonous series of light grey, more or less consolidated sandstones, usually weathering light yellowish grey. The series is mainly composed of rather poorly sorted, medium- to coarse-grained quartz sandstones with occasional layers and lenses of fine-grained sandstones and fine gravels. The sandstones contain a small amount of muscovite and a variable amount of feldspar makes subordinate parts of the series arkosic. The sandstones are massive to platy, or occasionally shaly, and usually cross-bedded. In some places layers or spherical portions are dark brown and hard from ferruginous cement.

Sometimes the sandstones contain a fairly large amount of dark organic detritus, and in a few places thin coal seams have been found. Some hard, dark siltstone root-beds are perhaps associated with these, but they were not found in situ.

Both trace fossils and body fossils are scarce in the upper main part of the Charcot Bugt Sandstone, and the state of preservation is poor. The trace fossils comprise vertical burrows, Curvolithus and Gyrochorte. The body fossils are mainly indeterminate impressions of lamellibranchs, but some pectinids and belemnites, as well as a few very poor casts of ammonites have been found. Impressions of fairly large fragments of wood occur in a few places.

The upper boundary of the Charcot Bugt Sandstone is very sharp and seems to represent slight erosion in connection with a short break in sedimentation. Thus, in many places the uppermost layers of the sandstone are hardened by ferruginous cement, and the basal layers of the succeeding sediments contain a thin conglomerate apparently composed of coarse components derived from the Charcot Bugt Sandstone imbedded in grey, shaly, fine-grained sandstone. 
Diagnostic fossils are rare in this formation. On the basis of a few occurrences of Perisphinctes (Arisphinctes) cf. maximus (Young and Bird) and $P$. (A.) cf. cotovui (Simionescu), Callomon (1961) referred the Charcot Bugt Sandstone to the Middle Oxfordian. A new find of a Perisphinctes in the basal part of the formation in the north-western part of the area seems to indicate a Middle Oxfordian age also of this part of the formation (J. H. Callomon, pers. comm. 1971).

\section{The "shale and glauconite series"}

This series is very widespread, covering the greater part of the main sedimentary area as shown in the map. In most places the shaly part of the series is badly covered by vegetation and talus.

Formal names for this formation and its subdivisions will be designated at a later date. In the description below, and on the map, it is divided into the "shale series", to the east subdivided by the "Pecten sandstone" into a lower and an upper part, and, above, the "glauconite series".

\section{The "shale series"}

The thickness of the "shale series", is about $500 \mathrm{~m}$ in the eastern part (including the "Pecten sandstone") and about $180 \mathrm{~m}$ in the western part (see fig. 7). Fossil evidence shows that the decrease in thickness to the west is most pronounced in the lower part of the sequence.

As mentioned above, the "shale series" commences with a very thin conglomerate, gradually passing up into the shales.

The "lower shale series", in the eastern part of the area is $c .200 \mathrm{~m}$ thick and consists of black and grey, micaceous, sandy and silty shales with subordinate sandy intercalations and concretionary horizons of sandy, more or less calcareous concretions.

The "upper shale series" in the eastern part is more than $200 \mathrm{~m}$ thick. It commences with a few metres of glauconitic, sandy, micaceous shale, passing into sandy and silty, micaceous shales containing huge, lenticular, concretionary bodies. Then follows a darker, more fine-grained and bituminous sequence, containing calcareous bands and concretions. The upper part of the sequence becomes gradually lighter in colour, the shales become more sandy and subordinate sandstone intercalations occur. Many horizons contain various sorts of sandy and calcareous concretions. The upper boundary is drawn at the first appearance of prominent glauconitic sandstone horizons in the sequence.

In the central and western outcrops the lithology of the "shale series", differs through the introduction of glauconitic horizons at several levels (see fig. 7).

The concretionary horizons of the "shale series" are very fossiliferous. A large amount of material from earlier collections (described by Spath 1935, 1936) are 


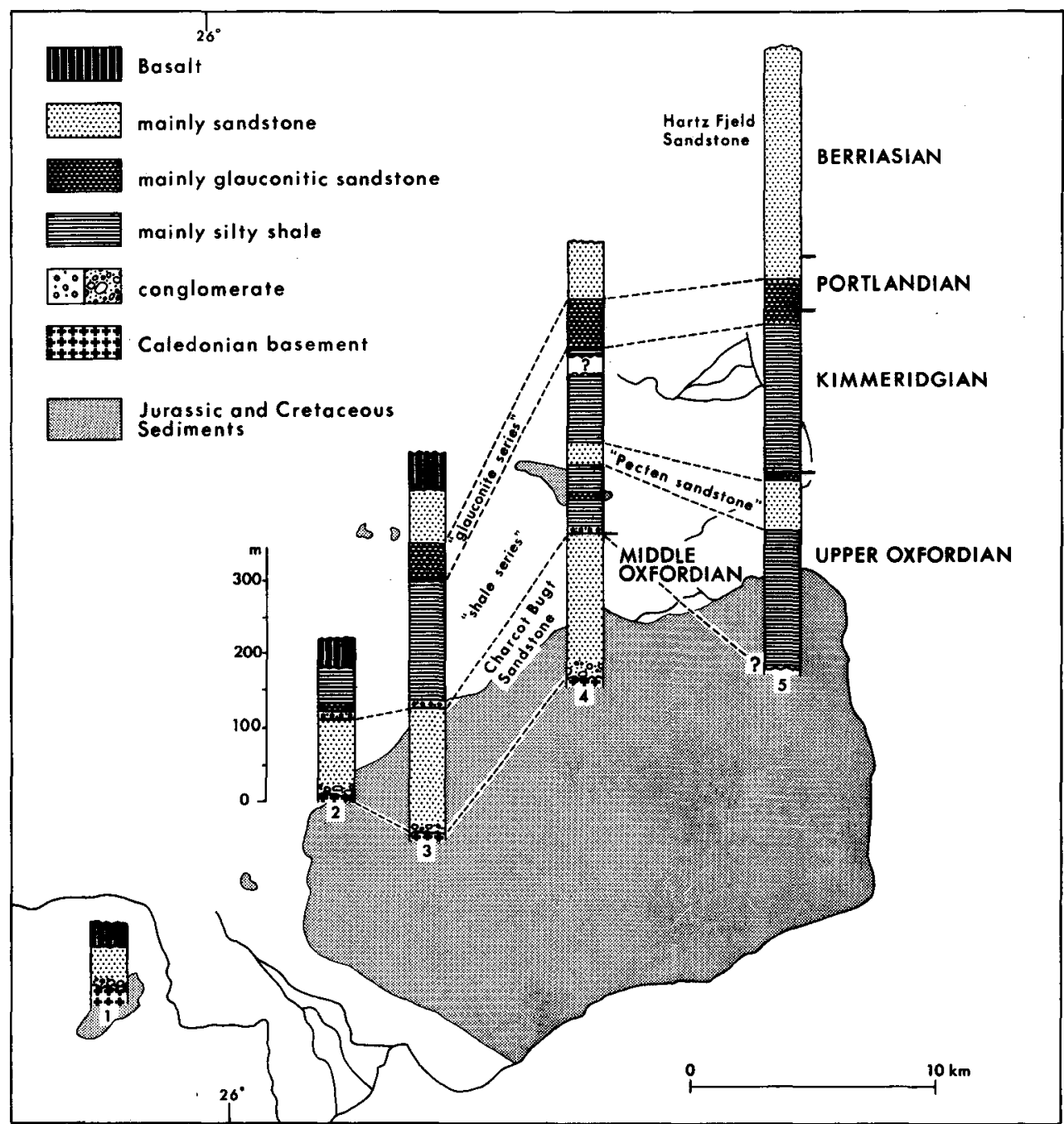

Fig. 7. Schematic sequences showing the stratigraphy of five localities in Milne Land.

from this part of the sequence. The new material collected supplements especially our knowledge of the Upper Oxfordian, and Lower and Middle Kimmeridgian part of the sequence. A description of new, well preserved Amoeboceras (Hoplocardioceras) spp., Aulacostephanus spp. and early Pectinatites spp. will be published elsewhere. In the Upper Kimmeridgian, ichthyosaur and plesiosaur skeletons were collected.

Trace fossils are rarely preserved in the shales. Only a few U-tubes and a Phycodeslike tube system with special wall structure were found in the "upper shale series". In 
concretions and concretionary layers of the lower as well as the "upper shale series", occur very slender, dark bodies of sediment some $2 \mathrm{~mm}$ in diameter, which were described by Aldinger as crustacean coprolites. Since they reach a length of several $\mathrm{cm}$ and do not follow bedding, it is considered more probable that they represent tunnels of sediment-eating animals. These are accompanied by Chondrites, Siphonites and Thalassinoides in the "lower shale series", and Curvolithus? in the upper.

Aldinger (1935) separated a number of horizons with concretions in the "upper shale series",(from below: $\delta, \gamma, \beta$ ) and considered that these horizons were characterised by distinct faunas. By 1936 Spath had already realised that some of $\mathrm{Al}$ dinger's individual concretion horizons contained ammonite faunas of different ages. Aldinger's horizon $\beta$, particularly, has caused confusion, as concretions of this type (containing crustaceans and "crustacean coprolites") seem to occur at several levels.

The "shale series" includes Upper Oxfordian and Lower, Middle and Upper Kimmeridgian (see Callomon, 1961). New collections supplement the Lower and Middle Kimmeridgian part of the zonal record given by Callomon (1961).

\section{The "Pecten sandstone"}

This sandy member in the middle part of the "shale series",forms a wedge thinning to the west. The thickness is greatest - 70 to $90 \mathrm{~m}$ - in the eastern part of the area. It decreases to $c .30 \mathrm{~m}$ north of Kronen, and from here it decreases further to $5 \mathrm{~m}$ in the southernmost exposures and finally it gradually disappears to the west.

The lower boundary is nowhere well exposed, but over most of the area there seems to be a rather gradual transition from the underlying dark shales to the "Pecten sandstone".

The "Pecten sandstone", consists mainly of poorly consolidated, light grey to yellowish, fine-grained sandstones, very rich in muscovite and commonly with dark organic detritus. In some horizons small scale cross-bedding occurs. Large, concretionary bodies are common and extremely fossiliferous in places. They show varying degrees of consolidation and sometimes form very irregular, more or less continuous layers.

Towards the north-east, where the thickness increases rapidly, the member becomes coarser and contains, especially towards the top, thick layers of well sorted, light grey, medium-grained, massive to thick-bedded sandstones, usually only slightly consolidated. In most of this region the "Pecten sandstone", weathers to a characteristic brownish hue.

In the western region the upper boundary of this unit seems to be merely a reverse repetition of the gradual transition of the lower boundary. To the north-east, however, the upper boundary is more distinct and in a single well exposed section it has been more closely investigated. It is here developed as a well-defined slightly irregular, rust-coloured plane separating the "Pecten sandstone" and the overlying dark 
grey, glauconitic shale. From this plane frequent, irregular, vertical burrows penetrate the uppermost layers of the sandstone, which are otherwise similar to the sandstone found further below.

Fossils are found throughout the "Pecten sandstone", but they vary considerably in density and diversity. Thus trace fossils are totally dominant in certain beds, whereas body fossils tend to be restricted to patches in which they occur in large quantities. They may be considered more or less allochthonous, although their state of preservation in general is good. The concentration of body fossils are found most frequently in the upper part of this sandstone in the western region and in the middle part of the sandstone in the north-eastern occurrences.

The collections from this part of the sequence supplement earlier collections considerably. Lamellibranchs, strongly dominated by pectinids, are most common. Less common are ammonites (amoeboceratids, perisphinctids), belemnites, crinoids, ophiuroids, echinoids, serpulids and vertebrate remains. Also pieces of silicified wood, representing trunks reaching at least $40 \mathrm{~cm}$ in diameter, have been found.

The trace fossil assemblages are different in the north-eastern and western parts of the area. In the north-eastern part the trace fossil assemblage is characterised by Curvolithus, Planolites and Gyrochorte. Certain beds have been totally burrowed through with Gyrochorte, which here reaches its greatest known vertical extension, namely $16 \mathrm{~cm}$. In the western part of the area the sandstónes are characterised by two sizes of tunnels with meniscus back-fill structure. Planolites also occurs, with a fill lacking mica, in contrast to the surrounding sediment.

The ammonite fauna of the "Pecten sandstone", indicates an Upper Oxfordian age (see Callomon, 1961).

\section{The "glauconite series",}

This series outcrops on Bays Fjelde, Kronen, Hartz Fjeld and its southern extension ("Lingula Ryg"). The outcrops at Hartz Fjeld and Kronen were described in some detail by Aldinger (1935), who stressed the remarkable lateral variation in lithology of this series.

The "glauconite series", varies in thickness between 50 and $90 \mathrm{~m}$, showing much local variation. At Hartz Fjeld and "Lingula Ryg", it is up to $90 \mathrm{~m}$ thick, being thickest on the north slope of Hartz Fjeld; at Kronen it is up to $80 \mathrm{~m}$ thick and in Bays Fjelde up to $c .70 \mathrm{~m}$.

The lower boundary of this series is placed at the first prominent glauconitic sandstone in the Upper Kimmeridgian shale sequence. The variation in thickness is partly due to introduction of these sandstones at different levels in the Upper Kimmeridgian shales.

The series consists of a number of glauconitic sandstone horizons intercalated with horizons of silty and sandy, micaceous shales very similar to the shales below.

The glauconitic sandstone horizons are usually massive. At the east slope of 
"Lingula Ryg", and Hartz Fjeld they consist of medium- to fine-grained, micaceous, well-sorted sandstones, weathering in greenish, reddish and brownish colours. Slightly coarser horizons occur on the north slope of Hartz Fjeld and Kronen. In many places the beds contain sandy concretions.

Especially on the north slope of Hartz Fjeld and at Kronen, prominent silty and sandy shales containing more or less calcareous concretions are intercalated between the glauconitic horizons.

On the eastern slope of "Lingula Ryg" and Hartz Fjeld the upper $20 \mathrm{~m}$ of the "glauconite series", consist of greyish, silty to sandy shales containing Aldinger's concretion horizon $\alpha$. These shales differ very clearly from the glauconitic horizons below. Elsewhere the series is terminated by glauconitic sandstones. The boundary with the Hartz Fjeld Sandstone is slightly irregular, but always knife-sharp. No burrows were seen at this junction.

The glauconitic sandstones are extremely fossiliferous, containing a great variety of ammonites (dominated by Pavlovia and Dorsoplanites spp.), belemnites, lamellibranchs, gastropods, brachiopods, crustaceans, serpulids and wood. The fossils are largely allochthonous, but Pinna is in some cases found in life position. The large majority of the fossils described by Spath originated from these beds. Trace fossils are not common. However, a rich assemblage of trace fossils in a layer low in the "glauconite series" can be recognised at several localities. On the north side of Hartz Fjeld this assemblage is dominated by Planolites, $1-2 \mathrm{~cm}$ thick, accompanied by meniscus tunnel-fills, and rarer Gyrochorte, vertical U-tubes and single shafts, and Thalassinoides. On the east side of Kronen the trace fossils are dominated by Curvolithus (type 2 of Heinberg, 1970). Gyrochorte, Planolites and vertical U-tubes also occur.

The age of the "glauconite series" is Upper Kimmeridgian-Portlandian (Callomon, 1961). Fossil evidence shows that the lower boundary, as defined by the first glauconitic sandstone horizon, is diachronous. Similarly, at the upper boundary, the greyish shales, containing Aldinger's $\alpha$ concretions, are slightly younger than the glauconitic beds found immediately below the Hartz Fjeld Sandstone in other parts of the area, probably indicating a slight unconformity (see Callomon, 1961).

\section{Hartz Fjeld Sandstone}

This formation forms the summits of Hartz Fjeld, "Lingula Ryg", and Kronen and is also present below the plateau basalt in Bays Fjelde. The greatest thickness, more than $300 \mathrm{~m}$, is found on Hartz Fjeld; on Kronen c. $75 \mathrm{~m}$ is preserved and c. $70 \mathrm{~m}$ in Bays Fjelde. The Jurassic-Cretaceous boundary falls within this formation.

The lower boundary of the formation is very sharp. It commences with $30-50 \mathrm{~m}$ thick medium- to coarse-grained, light coloured, micaceous quartz sandstone, containing a little feldspar and scattered dark organic detritus. The beds are poorly 
consolidated in the lowermost part, but pass rapidly into thick, unusually massive, cross-bedded sandstones. In Hartz Fjeld and "Lingula Ryg", some bedding planes are hardened by ferruginous cement and penetrated by vertical burrows. A single root-bed and casts of wood were also seen.

In "Lingula Ryg", this sequence is overlain by a very fossiliferous, 1-2 $\mathrm{m}$ thick marker bed (Aldinger's "Lingula bed"), consisting of greyish, medium- to coarsegrained, micaceous sandstone. The bed is thickest and most coarse-grained to the south. A diverse assemblage of lamellibranchs, gastropods and rare ammonites occurs in this bed, and bedding planes are often covered with shells of Lingula. Trace fossils are also abundant. Curvolithus (types 1 and 2 of Heinberg, 1970) is most common, but Gyrochorte and Planolites are also present.

In Hartz Fjeld, Kronen and Bays Fjelde another marker bed occurs, at about the same level as the "Lingula bed", consisting of poorly sorted sandstone crowded with casts of wood riddled in places by lamellibranch borings, together with rare casts of ammonites.

Above these marker beds the sequence consists of over $200 \mathrm{~m}$ of rhythmically alternating shaly or platy sandstone and massive sandstone. The shaly or platy sandstones are rather dark, especially in the upper part, fine-grained and often characterised by the trace fossils Curvolithus, Planolites, Thalqssinoides and in some places Gyrochorte. In one block a high mica content reveals the internal structures of Curvolithus, Gyrochorte, Planolites and Siphonites in unusual detail. The massive, light sandstones are similar in lithology to those below the marker beds. Ferruginous cement forms concretions and irregular layers at many levels and the upper boundary is often penetrated by vertical burrows. Few other trace fossils are seen in these beds except very poorly preserved crustacean? burrows of Cylindrites type, which are especially widespread in the sandstone at the boundary between Jurassic and Cretaceous deposits immediately above the "Lingula bed". Gyrochorte is also seen in the massive beds. Body fossils in the form of wood, poorly preserved lamellibranchs and ammonites are occasionally found at the top of the massive sandstones in the lower part of this sequence.

The upper part of this rhythmic sequence is dominated by dark, sandy shales. In Hartz Fjeld the top $70 \mathrm{~m}$ of the sequence consists of thick sandstones which are in places very coarse or conglomeratic. In this part of the sequence also a Curvolithus assemblage was seen in fine-grained intercalations.

The "Lingula bed" contains still a Middle Volgian fauna (viz. - Laugeites) and $15 \mathrm{~m}$ higher Berriasian Tollia spp. occur (Callomon, 1961; Donovan, 1964). In the light sandstones in between the only fossils found were probable crustacean burrows.

The plateau basalts seem to rest on a very irregularly eroded surface. Downward creeping of basalt talus renders the junction poorly exposed and hence difficult to map. 


\section{The map}

The preliminary map (map 2) is very similar to Aldinger's map of the eastern part of the area. It differs mainly in the interpretation of the area east of "Lingula Ryg" and parts of Hartz Fjeld as covered by extensive land slides instead of as down-faulted blocks.

Only very minor faults occur. The sediments dip a few degrees in a south-eastern direction.

The dykes are usually only a few metres thick and are therefore not drawn to scale.

\section{Acknowledgements}

Grateful thanks are offered to Dr. J. H. Callomon for his helpful discussion of stratigraphical and palaeontological problems and to Dr. R. Bromley for improving the English text.

\section{References}

Aldinger, H. 1935: Geologische Beobachtungen im Oberen Jura des Scoresbysundes (Ostgrönland). Meddr Gronland 99, 1, 128 pp.

Callomon, J. H. 1961: The Jurassic System in East Greenland, In Raasch, G. O. (edit.) Geology of the Arctic 1, 258-268. Toronto U: P.

Donovan, D. T. 1964: Stratigraphy and ammonite fauna of the Volgian and Berriasian rocks of East Greenland. Meddr Gronland 154, 4, 34 pp.

Heinberg, C. 1970: Some Jurassic trace fossils from Jameson Land (East Greenland). In Crimes, T. P. \& Harper, J. C. (edit.) Trace fossils. Geol. J. spec. Issue 3. Liverpool : Seel House Press, 227-234.

Rosenkrantz, A. 1929: Preliminary account of the geology of the Scoresby Sound District. Meddr Gronland 73, 2, 135-154.

Spath, L. F. 1935: The Upper Jurassic invertebrate faunas of Cape Leslie, Milne Land. I. Oxfordian and Lower Kimmeridgian. Meddr Grønland 99, 2, 82 pp.

Spath, L. F. 1936: The Upper Jurassic invertebrate faunas of Cape Leslie, Milne Land. II. Upper Kimmeridgian and Portlandian. Meddr Gronland 99, 3, 180 pp. 